TP Periodica Polytechnica Chemical Engineering

62(2), pp. 175-181, 2018

https://doi.org/10.3311/PPch.11078

Creative Commons Attribution (i)

RESEARCH ARTICLE

\section{Classification and Identification of Three Vintage Designated Hungarian Spirits by Their Volatile Compounds}

Attila G. Kovács ${ }^{1}$, Attila Szöllősi ${ }^{1}$, Dániel Szöllősi², Ilona A. Panyik ${ }^{1}$, László Nagygyörgy ${ }^{3}$, Ágoston Hoschke ${ }^{1}$, Quang D. Nguyen ${ }^{1 *}$

Received 26 May 2017; accepted 01 June 2017

\begin{abstract}
The quality of fruit based spirits varies year to year; therefore, the identification of the vintage of a distilled alcoholic beverage is necessary, but requires highly sensitive analytics. The interpretation of the gathered data requires a well-adapted chemometric method. In this study, Hungarian apple, sour cherry and plum distillates (pálinka's) from different vintages were analyzed, classified and identified using volatile composition analyzed by GC-MS. The fruit's origin, fermentation technique and distillation were the same at all the fruits; the only differences in the samples were their vintages (2010, 2011 and 2012). Analysis of variance (ANOVA) and Linear discriminant analysis (LDA) was applied for classification and components' identification related to the vintage effect. The samples were successfully classified (correct classification rate ranging from 75 to $100 \%$ ), three components are found to be related to the vintage effect regardless the fruit type: propanol, butanol and ethyl-propionate. GC-MS data proved to be a promising tool for classification of fruit distillate vintages.
\end{abstract}

\section{Keywords}

gas chromatography mass spectrometry (GC-MS), linear discriminant analysis (LDA), vintage, pálinka

\footnotetext{
${ }^{1}$ Department of Brewing and Distilling, Faculty of Food Science, Szent István University, H-1118 Budapest, Ménesi út 43-45., Hungary

${ }^{2}$ Medical University of Vienna, Institute of Pharmacology, Vienna 1090, Austria
}

${ }^{3}$ WESSLING Hungary Ltd. H-1047 Budapest, Fóti út 56., Hungary

*Corresponding author, e-mail: Nguyen.Duc.Quang@etk.szie.hu

\section{Introduction}

The vintage of an alcoholic beverage is one of the markers which helps one determine whether a beverage will meet one's expectations or not. Among the data regarding vintage, the year of cultivation is one of the key pieces of information which one finds on the label. Having the same producer, the same fruits from the same cultivation sites, gardens, and the same process technology - the only difference being the year of cultivation can cause outstanding differences in the sensory quality of the products. In the case of fruit/grape based alcoholic beverages, the 'vintage' refers to the year the fruits are harvested. Fruitbased alcoholic beverages, containing mostly fruit related compounds, affect the aroma profile in proportion to the amount of the compounds. The aroma profile changes year by year depending on weather patterns which the cultivation sites are exposed to. Product quality also depends on the timing of the harvest and the soil's chemical composition [1-3]. The climate can influence fruit quality [4]; different environmental factors in each year's vegetation period can result in a variation of a vintage's fruit quality. Aroma compounds are heavily influenced by the climate [5], the climate variations between different harvests are responsible for the vintage effect at the wines $[6,7]$. In literature, limited publication could be found about the effect of yearly weather patterns on the quality of the fermented fruit based spirits.

Pálinka is a Hungarian spirit made of fruit and it is either double distilled or distilled on a rectifier column [8]. Some alcoholic beverages are less influenced by the yearly climate, since they contain less primary aromas (fruit origin) and more secondary and tertiary ones which come from the fermentation, aging or flavoring processes. Pálinka-s, on the other hand, contain relatively more primary aromas than secondary or tertiary aromas in the final product, which is why the quality of the fruit - the quality of which changes year by year due to the climate - matters. Some industries, such as wine and fats-andoils, have recognized the significance of these climate effects on their products. Analytical and sensory studies have been published about the measurement and practical significance of these effects in various journals $[9,10]$. 
Vintage designation on beverages is one of the few identification and quality markers that manufacturers use. This way customers can recognize a certain spirit and estimate the quality of the purchased product compared to the price they paid for it, versus a competitor's product. The hours of sunlight, precipitation, average, maximum and minimum temperature in the vegetation period has a major effect on the quality of the budding fruits. In this way it has a major effect on the product made of the fruit. Soluble sugars, titrable acidity, nitrogen and phenolic compound balance contribute to characterize grape quality. The value of these factors varies with genetic and environmental (climate, soil, vintage) factors.

A broad range of studies have been published regarding the effects of vintage on grapes and its derivatives. Pereira et al. [11] conducted a study to determine the changes in the metabolite fingerprints of grape berry skins of 'Merlot noir', 'Cabernet franc' and 'Cabernet Sauvignon' cultivars harvested in 2002, 2003 and 2004, from five geographical locations in Bordeaux, France, to better understand the factors influencing grape berry composition. They found that the vintage effect on grape metabolic profiles prevailed over the soil effect. In Australia, regarding wine quality, climate change seems to have had a major effect on the chemical composition of the products. The Australian climate has shifted from El Niño to La Niña. Stockham et al. [12], present the influence of climate conditions and growing regions on the in-vitro and ex-vivo antioxidant capacity of red and white wine, and the profile and concentration of polyphenols in these wines from the 2008 and 2009 vintages.

Several chemometric methods are used to describe the similarities and dissimilarities between samples based on multivariate data: linear discriminant analysis (LDA), principal component analysis (PCA), multiple factor analysis (MFA), parallel factor analysis (PARAFAC), partial least squares regression (PLS-R), detrended fluctuation analysis (DFA), correspondence analysis (CorrA), cluster analysis (CA) [1,5].

In 2005, study [13] established relationships between sensory attributes and the cider distillates on the basis of the raw material used in their manufacture and aging level by using Principal Component Analysis. Three sensory descriptors (smoothness, nutty and toasty) were predicted with good accuracy using 7 aromas as predictor variables and a Partial Least Squares (PLS) model with 2 principal components.

Lee et al. [14] investigated the effects of grape vintages on metabolic profiles of wine, and the relationship between wine metabolites and meteorological data. They showed a clear differentiation between the Meoru grape wines which were harvested from the same vineyard and fermented with the same yeast strain, but with a different vintage. The metabolites contributing to the differentiation were identified as 2,3-butandiol, lactic acid, alanine, proline, $\gamma$-amino-butyric acid, choline and polyphenols. Higher levels of proline, lactic acid and polyphenols were observed in the 2006 vintage wines compared to those of the 2007 vintage, showing a strong correlation with the meteorological data. In 2006, the sun exposure and rainfall were approximately two times more and four times less, respectively, than those in 2007.

In the literature, there are few articles which deal with pálinka analytics; for instance, Deák et al. [8] published a study about an ethyl carbamate determination method in pálinka products using HPLC-ESI-MS/MS. Majoros and co-authors [17] studied apricot pálinka and synthetic apricot alcoholic beverages; they proved that real apricot pálinka contains more compounds than the aroma-added beverage, and its composition can be interpreted as a fingerprint. Panyik and Beli (2008) write in their book about specific territories which are exceptional for specific fruit cultivation. Their book states that spirits made from these fruits have a higher quality than identical fruits from other regions of the country. Plum distillates from the Polish region Łacko as well as Polish commercial Sliwowica, Slovak Slivovica and Romanian Plum Tzuica from Cluj-Napoca have been studied by their chemical composition (ethanol, acetaldehyde, ethyl acetate, methanol, 1-propanol, isobutanol, butanol, amyl alcohols, pentanol, 1-hexanol, 2-phenyl-ethanol, acetic acid and hydrogen cyanide). Cluster analysis clearly differentiated Polish 'Sliwowica Lacka' spirits from the others. In addition, statistically significant differences were found in the plum brandy sensory characteristics [18].

Our motivation in this research was to distinguish fruit distillates of the same cultivar, origin and process technology but from different vintages based on data from GC-MS.

\section{Materials and Methods \\ 2.1 Materials}

Jonathan (Malus domestica 'Jonathan') apple was bought from Tuzsér located farmers. Jonagold (Malus domestica 'Jonagold') and Relinda (Malus domestica 'Relinda') apples were cultivated in the town of Vásárosnamény. The two cultivation territories neighbor each other.

Plum (Prunus domestica) fruits originating from a special territory of Hungary called Békés, known for its high-quality plum cultivation. Plum cultivars were Prunus domestica var. Rodna, Prunus domestica var. Penyigei and Prunus domestica var. Stanley.

Sour cherry (Prunus avium) fruits were a symphoricarpous sour cherry cultivar called 'Újfehértói fürtösmeggy' (Prunus avium var. Újfehértói) and collected from the same culture each year which is located in the North-Eastern region of Hungary, near the town of Ujfehértó, the territory of the country is best known for its high quality sour cherry fruit.

Every year (2010, 2011 and 2012) the fruit was provided by farmers from the above-mentioned territories. Ripeness, fruit health and fruit integrity parameters were set to assure as much similarity between different vintages as possible. 
The yeast Saccharomyces cerevisiae 228 strain was purchased from the Kokoferm Company (Gyöngyös, Hungary).

Phosphoric and lactic acids were bought from VWR International Co. (Debrecen, Hungary).

\subsection{Meteorological data}

In order to expect a difference among the pálinka samples between the different years we assume that these vintages differ in their climate. Meteorological data was collected from four Hungarian towns (Újfehértó, Tuzsér, Vásárosnamény and Békés) covering the cultivation area of the tested fruits [19]. Because of the short geographical distance between the cities their climate is very similar, there was no climatic difference registered between the cities of cultivation. Averaged data of each vintage is shown in Table 1 . The amount of rainy days, high temperature days, exposure to sunlight, and precipitation quantity influenced the fruit's chemical composition. 2010 was a rainy year while 2011 and 2012 were dry. In 2011, not only was precipitation limited but the heat was much higher than in the previous or following years. The meteorological differences between different vintages can cause different fruit quality [20-23], which will further effect the product quality of the beverage that is made of the fruit.

Table 1 Climate data of the 2010, 2011 and 2012 vintages

\begin{tabular}{llll}
\hline & \multicolumn{3}{c}{ Climate data } \\
\cline { 2 - 4 } Vintage & 2010 & 2011 & 2012 \\
\hline Average temperature ${ }^{\circ} \mathrm{C}$ & 9.7 & 10.4 & 10.9 \\
Sunny hours in a year, h & 1893.1 & 2289 & 2296.9 \\
Number of rainy days & 185 & 109 & 113 \\
Precipitation, mm & 1166 & 483.9 & 518.6 \\
Total temperature in vegetation period, ${ }^{\circ} \mathrm{C}$ & 1245 & 1512 & 1581 \\
Average temperature of vegetation period & 16.9 & 18.4 & 18.8 \\
Number of heat days & 23 & 44 & 35 \\
Precipitation in vegetation period, mm & 812.9 & 353.1 & 359 \\
\hline
\end{tabular}

\subsection{Sample preparation}

The identified discriminating compounds may have two different origins; fruit and yeast metabolism. The similar sample preparation ought to minimize the differences which come from the latter source and gain the significance of the former.

The fermentation was performed on a semi-industrial scale to represent similar conditions as those used in a manufacturing process. Fruits were washed in tap water before the mashing procedure. Slicing and disintegration of the fruit was carried out using a grinder. Cherries were de-pitted during the crushing process. The broth was transferred into $50 \mathrm{~L}$ stainless steel fermentation tanks separately. The running volume of the tank was $80 \%$, which meant $40 \mathrm{~L}$ fruit mash was transferred into the tank. At the very beginning, before the alcoholic fermentation began, the $\mathrm{pH}$ of the broths was adjusted to $\mathrm{pH}$ 3.0 using $25 \% \mathrm{~V} / \mathrm{V}$ phosphoric acid with $10 \% \mathrm{~V} / \mathrm{V}$ lactic acid content. Then $20 \mathrm{~g} / 100 \mathrm{~kg}$ Uva-Vital yeast nutrient was added to each tank. Polygalacturonase enzyme (Lallemand Company, Ontario, Canada) was used in dose of $3 \mathrm{~g} / 100 \mathrm{~kg}$ to decompose the pectin and reduce methanol production. Fermentation was started by adding rehydrated yeast inoculation and carried out at $16{ }^{\circ} \mathrm{C}$ for 10 days. Rehydration of the dried yeast was performed in sterile flasks using sterile $1 \mathrm{M} \mathrm{NaCl}$ solution, glucose $(2 \mathrm{~g} / \mathrm{L})$, and sterilized yeast nutrient solution $(7 \mathrm{~g} / \mathrm{L})$. The mixture was incubated in a horizontal shaker for 1 hour before use.

In the research 11 apple batches, 11 sour cherry batches and 17 plum batches were fermented annually.

\subsection{Distillation}

The fermented fruit mash was distilled on a rectifier column equipped, steam heated still made by the Hagyó Spirit Company (Miskolc, Hungary). The distillation unit was controlled by computer where condenser temperature, reflux ratio and heating program could have been changed through Hagyó software, Révész (Hagyó Spirit Company, Hungary). The distillation program began by heating at $100 \%$ until the mash reached $80{ }^{\circ} \mathrm{C}$, then heating at $50 \%$ until the lower plate in the rectifier column reached $70{ }^{\circ} \mathrm{C}$. When the target temperature $\left(70{ }^{\circ} \mathrm{C}\right)$ was reached, $20 \%$ heating was applied until the steam pipe to the final condenser reached $80^{\circ} \mathrm{C}$. As $80^{\circ} \mathrm{C}$ was measured in the steam pipe which goes to the final condenser, $15 \%$ heating was used - this gradually rose to $20 \%$ as the distillation progressed in time. The rectifier column was equipped with three physical trays, each tray bearing a bubble cap: the lower tray had $70 \%$ fluid on it, the middle tray had $45 \%$ fluid on it, while the upper tray was bearing only $15 \%$ condensate, which was flowing back as reflux from the dephlegmator (tube condenser).

After fermentation, all batches were distilled separately. To minimize batch to batch variations deriving from distillation heads, hearts and tails cuts were made by the computer by switching valves. At each distillation $40 \mathrm{ml}$ of heads was collected. The software switched to hearts automatically after $40 \mathrm{ml}$ of heads distillate flow. Hearts were collected until the vapor pipe's temperature reached $88.0^{\circ} \mathrm{C}$, then the software automatically switched to tails, and collected $200 \mathrm{ml}$ of tails. The collection of the $200 \mathrm{ml}$ sample was followed by the stop sequence, which stopped heating, condenser cooling, agitation and dephlegmator. Hearts were stored for 14 days before analysis.

\subsection{GC-MS method}

Volatile compounds were identified by a GC-MS apparatus using an Agilent 6890 gas chromatograph attached to an Agilent 5973 mass spectrometer (monolithic hyperbolic quadrupole). The study used a fiberglass filled split/splitless injector: injected volume was $1 \mu 1$, a 1:100 split was applied, injector temperature was $240{ }^{\circ} \mathrm{C}, 1 \mathrm{~mL} / \mathrm{min}$ Helium as carrier gas in 
isochoric conditions was used with column: ZB-Wax $30 \mathrm{~m} \times$ $0.25 \mathrm{~mm} \times 0.25 \mu \mathrm{m}$. Temperature program: $40{ }^{\circ} \mathrm{C}(2.5 \mathrm{~min})$, $8{ }^{\circ} \mathrm{C} / \mathrm{min}$ heat up until $170^{\circ} \mathrm{C}$ was reached, $35^{\circ} \mathrm{C} / \mathrm{min}$ heating step was applied until $240^{\circ} \mathrm{C}$ was reached for $3.25 \mathrm{~min}$, transfer line temperature program: $170{ }^{\circ} \mathrm{C}(18.5 \mathrm{~min})$, until $35^{\circ} \mathrm{C} / \mathrm{min}$ $240{ }^{\circ} \mathrm{C}$ (3.5 min) was reached.

The mass detector was in Selective Ion Monitoring (SIM) mode, at ionization energy $70 \mathrm{eV}$ and at source temperature $230{ }^{\circ} \mathrm{C}$. The quadrupole analyzer temperature was $150{ }^{\circ} \mathrm{C}$. There was no sample preparation for the alcoholic beverages; the samples were analyzed directly without any modification. 3-pentanol $250 \mathrm{mg} / \mathrm{L}$ internal standard was used as an injection standard only (according to 2870/2000/EC Regulation), thus recovery yield calculation was not performed. Makeup gas was not applied. Gas chromatographic analyses were carried out in Wessling Company, using an accredited method (WBSE61:2010) in the accredited laboratory (NAT-1-1009/2012, valid trough: 2016-04-17).

\section{Results and Discussion \\ 3.1 ANOVA test of the relation between pálinka compounds and vintage}

Each pálinka compound were tested with one-way ANOVA in order to find relation with the vintage. Results of one-way ANOVA of individual pálinka compounds are shown in Table 2. It is clearly shown that while apple has only a small fraction of compounds differing in the different years, sour cherry and plum had numerous which indicates that apple is a less vintage sensitive fruit.

The quality and quantity of volatile compounds present in ripening apple fruits are cultivar-specific [24]. Jonathan and Jonagold apples are characterized as containing low alcyl-ester (except for ethylhexanoate) and the high cis-3-hexen-1-ol and trans-2-hexenal containing apples with intermediate concentrations of hexanal and 2-methylbutanol. No comparative data could be found concerning these data about the 'Relinda' apple. Our results are in agreement with ones by Lopez et al. $[25,26]$, and Villatoro et al. [27] when the best described or identified compounds of the apples are ethyl butanoate, ethyl 2-methylbutanoate, 2-methylbutyl acetate, hexyl acetate, hexyl propanoate, hexyl hexanoate, hexyl 2-methylbutanoate hexyl acetate, hexyl butanoate, hexyl 2-methylbutanoate, hexyl hexanoate, butyl acetate, 2-methylbutyl acetate, ethyl butanoate and ethyl hexanoate. These compounds give no significant variance between the different apple vintages, thus apple varieties are vintage independent, but they can serve as a fingerprint in apple identification even among different years. However, in the point of view of vintage identification, these compounds are not yet in our interest.

The most abundant compounds identified in the fresh plum were hexanal, hexan-1-ol, hex-3-en-1-ol, hex-3-enyl acetate, hexyl acetate and hex-2-enal. In general, most of the volatiles isolated were present in very low concentrations. The major compounds detected in the present study were also identified in plum by other authors [30-33].

Acetaldehyde is the terminal electron acceptor in the alcoholic fermentation. It is a reactive, low molecular weight, flavor active compound found in a variety of foods and beverages. Specific acetaldehyde resemble the green apple, and fresh cut grass aroma [34]. The presence of acetaldehyde in high concentrations has been suggested to be the result of fruit cell metabolism and limited gas diffusion $[35,36]$. Its concentration does not only depend on the fruit cultivar, but also on the ripeness too.

Some aldehydes and esters were also measured as key volatiles of plum [32].

Table 2 One-way ANOVA results of individual pálinka compounds

\begin{tabular}{|c|c|c|c|c|}
\hline Parameter & Apple & Sour cherry & Plum & Common \\
\hline acetaldehyde & $* * *$ & $* *$ & $* * *$ & 1 \\
\hline acetal & & $* * *$ & $* * *$ & 0 \\
\hline propanol & $* * *$ & $* * *$ & $* * *$ & 1 \\
\hline i-butanol & $* * *$ & $* * *$ & & 0 \\
\hline 1-butanol & $* * *$ & $* *$ & $* * *$ & 1 \\
\hline 2-methyl-1-butanol & & $* * *$ & $* * *$ & 0 \\
\hline 3-methyl-1-butanol & $* * *$ & $* * *$ & & 0 \\
\hline Me-butanols & & & $*$ & 0 \\
\hline ethyl-propionate & * & $* * *$ & $* * *$ & 1 \\
\hline ethyl-butanoate & & $* *$ & $* * *$ & 0 \\
\hline 2-methylbutyl acetate & & $* * *$ & $* * *$ & 0 \\
\hline 3-methybutyl acetate & $* * *$ & $* * *$ & & 0 \\
\hline Me-Bu-acetates & $*$ & & $* * *$ & 0 \\
\hline ethyl hexanoate & * & & $* *$ & 0 \\
\hline hexyl acetate & & $* * *$ & $* * *$ & 0 \\
\hline ethyl lactate & & $*$ & $* * *$ & 0 \\
\hline ethyl octanoate & & & $* * *$ & 0 \\
\hline ethyl decanoate & & $*$ & $* * *$ & 0 \\
\hline ethyl-benzoate & & & $* *$ & 0 \\
\hline ethyl-dodecanoate & & & $* * *$ & 0 \\
\hline 2,3-butadiene & & $* *$ & $* * *$ & 0 \\
\hline 2,3-pentadiene & & & $* * *$ & 0 \\
\hline allyl alcohol & $* * *$ & $* * *$ & & 0 \\
\hline 2-phenilethanol & & & & 0 \\
\hline
\end{tabular}

Significance: $0 * * * 0.001 * * 0.01 * 0.05 * 0.1$

\subsection{Discriminant Analysis}

In order to analyze the effect size of the different components in differentiating the vintages, linear discriminant analysis was performed. In the evaluation, only the components which were previously shown with ANOVA to have significant difference among the years as a feature selection method, were 
involved. Moreover, it is worth to note that samples in the same vintage from different species either of apple or plum were not able to group separately, thus discussions regarded to species were not further performed in this paper.

\subsubsection{Apple distillates}

The frequencies of apple vintage categories were balanced - 11 (2010), 11 (2011), 11 (2012) - requiring no weighing in the statistics. The linear discriminant analysis of apple samples (Fig. 1) shows that the samples can be differentiated with some overlapping. The total correct classification rate was $75.8 \%$. By analyzing the relation of the discriminant variables (LD12) with the original GC-MS component concentrations using the LDA coefficients we found that the discrimination among the different vintages relates to 2-methyl-1-butanol, 2-methylbutyl acetate, 3-methyl-butyl acetate and methyl-butyl acetates. This means that building a discrimination model using only the data of these components would result a similar LDA in terms of discrimination (not shown) and accuracy (correct classification 78.8\%). 2-methylbutanoate esters, especially ethyl 2-methylbutanoate, are key contributors to fruit aromas [28]. Sensory evaluation of apples revealed that 2-methylbutyl acetate is a major flavor contributor in apples. Fuhrmann and Grosch [29] showed that acetaldehyde, 2-methyl-1-butanol and methyl-butanoate concentrations in apples are not only cultivar specific, but their concentration in the samples can differ with the sample preparation too.

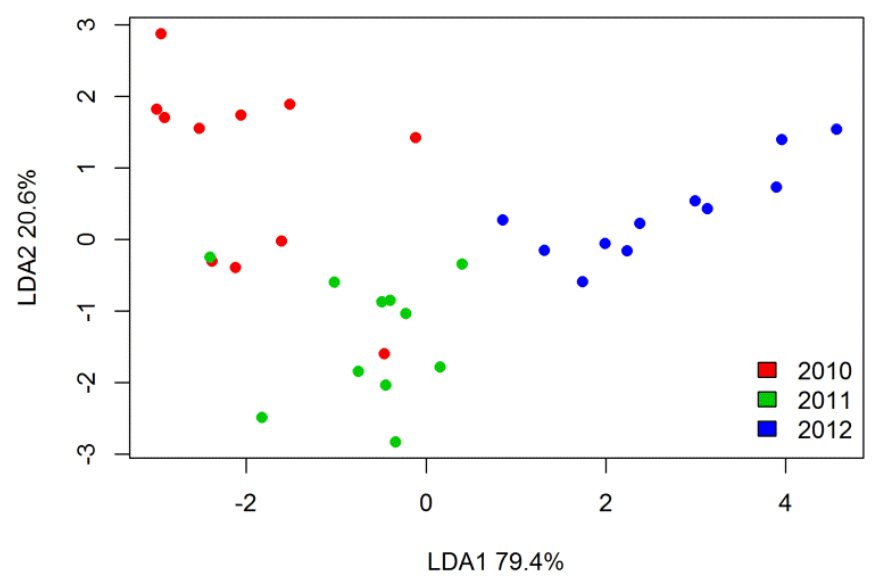

Fig. 1 LDA plot of the apple distillate vintages

\subsubsection{Sour cherry distillates}

LDA results of the sour cherry data is shown in Fig. 2. However the figure shows excellent discrimination, cross-validation indicates a model accuracy of $87.8 \%$. The compounds which are responsible for the main differences among vintages are: ethyl-propionate, 2-methylbutil acetate, 3-methylbutil acetate, methylbutil acetates (Me-Bu-acetates), linalool and allyl-alcohol.

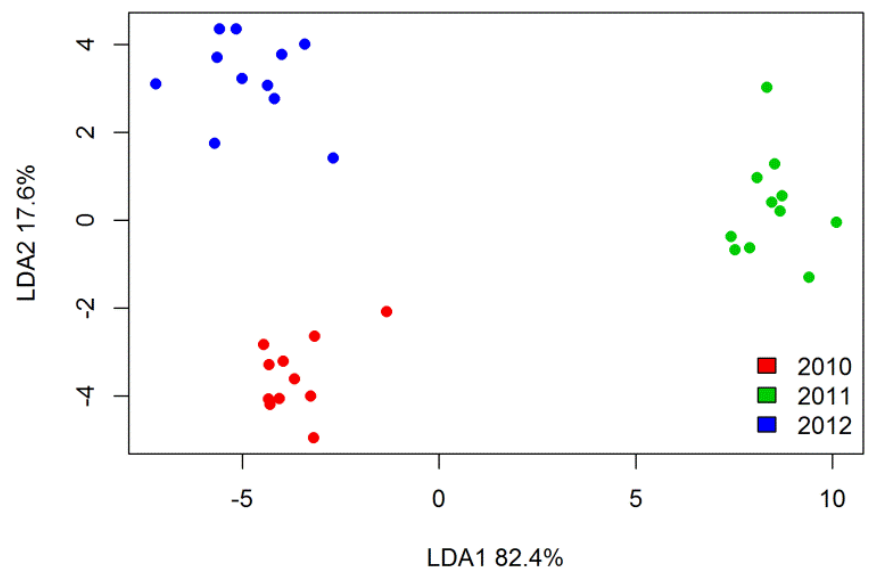

Fig. 2 LDA plot of the sour cherry distillate vintages

\subsubsection{Plum distillates}

The linear discriminant analysis of plum samples (Fig. 3) show that the samples can be differentiated without any misclassification. By analyzing the relation of the discriminant variables (LD1-2) with the GC-MS component concentrations similarly as for the apple samples the components contributing to the vintage discrimination were: ethyl-propionate, ethyl-butanoate, ethyl-hexanoate, 2,3-pentadiene and ethyl-dodecanoate. The high discriminability of plum samples indicate that plum is the most sensitive fruit for meteorological differences and vintage identification is the most important.

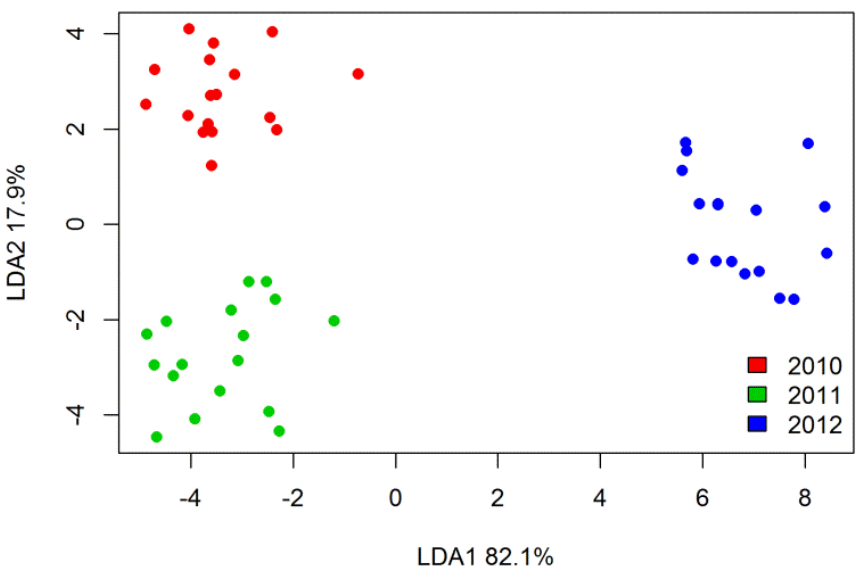

Fig. 3 LDA plot of the plum distillate vintages

All the LDA figures showed that the sample groups of different vintages are placed on the corners of an imagined triangle. This arrangement indicates that the all samples are different from all others and do not follow a certain trend. This later result suggests that every vintage is different but unfortunately in an unpredictable way. The consequence of this result for later measurements is that reference samples will be necessary on order to predict an unknown samples vintage. 
The discriminating components were different for the distinct fruits of course with some minor overlap, which indicates that at the moment we cannot establish a common vintage prediction model and there is no weather-reporting component at least among the tested ones.

\section{Conclusions}

The effect of vintage on fruit distillates has been studied for the first time. Combining the GC-MS hyphenated method with multivariate statistical analysis, we succeeded in discriminating between different vintage distillates which had the same origins, were processed and fermented using the same technology at the same location, and were distilled using the same equipment with the same equipment settings. Using discriminant analysis (DA) we identified the compounds which appeared to be responsible for the identification of the different plum, apple and sour cherry distillate vintages, however, these components were different fruit by fruit. Based on the analyzed samples no trend was observed among the samples which suggest that every year differs in a different way from the others, hence in vintage identification measurements application of reference samples are necessary. The efficient discriminations were verified, cross validation tests resulted in high values of correlation. This method could be used to attest vintage designation on such products where product quality changes year by year.

\section{Acknowledgements}

The authors would like to thank Mr. Bob Atkins for his helpful assistance. This work is supported by National Development Agency (Project no. TÁMOP-4.2.1./B-09/1KMR-2010-0005, TÁMOP-4.2.2/B-10/1-2010-0023 and TECH_09-A3-2009-0194), as well as Bolyai Research Grant from Hungarian Academic of Sciences.

\section{References}

[1] Lukić , I., Radeka, S., Grozaj, N., Staver, M., Persuric, D. "Changes in physico-chemical and volatile aroma compound composition of Gewurztraminer wine as a result of late and ice harvest." Food Chemistry. 196, pp. 1048-1057. 2016.

https://doi.org/10.1016/j.foodchem.2015.10.061

[2] Vilanova, M., Genisheva, Z., Bescansa, L., Masa, A., Oliveira, J. M. "Changes in free and bound fractions of aroma compounds of four Vitis vinifera cultivars at the last ripening stages." Phytochemistry. 74, pp. 196-205. 2012.

https://doi.org/10.1016/j.phytochem.2011.10.004

[3] Echeverria, G., Fuentes, T., Graell, J., Lara, I., Lopez, M. L. "Aroma volatile compounds of 'Fuji' apples in relation to harvest date and cold storage technology - A comparison of two seasons." Postharvest Biology and Technology. 32(1), pp. 29-44. 2004.

https://doi.org/10.1016/j.postharvbio.2003.09.017

[4] Martin, D., Grose, C., Fedrizzi, B., Stuart, L., Albright, A., McLachlan,

A. "Grape cluster microclimate influences the aroma composition of Sauvignon blanc wine." Food Chemistry. 210, pp. 640-647. 2016. https://doi.org/10.1016/j.foodchem.2016.05.010
[5] Xu, X. Q., Liu, B., Zhu, B. Q., Lan, Y. B., Gao, Y., Wang, D., Reeves, M. J., Duan, C. Q. "Differences in volatile profiles of Cabernet Sauvignon grapes grown in two distinct regions of China and their responses to weather conditions." Plant Physiology and Biochemistry. 89, pp. 23-133. 2015. https://doi.org/10.1016/j.plaphy.2015.02.020

[6] Roullier-Gall, C., Boutegrabet, L., Gougeon, R. D., Schmitt-Kopplin, P. "A grape and wine chemodiversity comparison of different appellations in Burgundy: Vintage vs terroir effects." Food Chemistry. 152, pp. 100-107. 2014. https://doi.org/10.1016/j.foodchem.2013.11.056

[7] Rayne, S., Forest, K. "Rapidly changing climatic conditions for wine grape growing in the Okanagan Valley region of British Columbia, Canada." Science of the Total Environment. 556, pp. 169-178. 2016. https://doi.org/10.1016/j.scitotenv.2016.02.200

[8] Deak, E., Gyepes, A., Stefanovits-Banyai, E., Dernovics, M. "Determination of ethyl carbamate in palinka spirits by liquid chromatographyelectrospray tandem mass spectrometry after derivatization." Food Research International. 43(10), pp. 2452-2455. 2010.

https://doi.org/10.1016/j.foodres.2010.09.014

[9] Lorrain, B., Chira, K., Teissedre, P. L. "Phenolic composition of Merlot and Cabernet-Sauvignon grapes from Bordeaux vineyard for the 2009-vintage: Comparison to 2006, 2007 and 2008 vintages." Food Chemistry. 126(4), pp. 1991-1999. 2011.

https://doi.org/10.1016/j.foodchem.2010.12.062

[10] Lopez-Giral, N., Gonzalez-Arenzana, L., Gonzalez-Ferrero, C., Lopez, R., Santamaria, P., Lopez-Alfaro, I., Garde-Cerdan, T. "Pulsed electric field treatment to improve the phenolic compound extraction from Graciano, Tempranillo and Grenache grape varieties during two vintages." Innovative Food Science \& Emerging Technology. 28, pp. 31-39. 2015. https://doi.org/10.1016/j.ifset.2015.01.003

[11] Pereira, G. E., Gaudillere, J. P., van Leeuwen, C., Hilbert, G., Maucourt, M., Deborde, C., Moing, A., Rolin, D. "H-1 NMR metabolite fingerprints of grape berry: Comparison of vintage and soil effects in Bordeaux grapevine growing areas." Analytica Chimica Acta. 563(1-2), pp. 346-352. 2006. https://doi.org/10.1016/j.aca.2005.11.007

[12] Stockham, K., Sheard, A., Paimin, R., Buddhadasa, S., Duong, S., Orbell, J. D., Murdoch, T. "Comparative studies on the antioxidant properties and polyphenolic content of wine from different growing regions and vintages, a pilot study to investigate chemical markers for climate change." Food Chemistry. 140(3), pp. 500-506. 2013. https://doi.org/10.1016/j.foodchem.2013.01.006

[13] Lobo, A. P., Madrera, R. R., Alonso, J. J. M. "A study of cider distillates using sensory and chromatographic data and chemometric analysis." Journal of Food Science. 70(3), pp. S204-S207. 2005. https://doi.org/10.1111/j.1365-2621.2005.tb07158.x

[14] Lee, J. E., Hwang, G. S., Van Den Berg, F., Lee, C. H., Hong, Y. S. "Evidence of vintage effects on grape wines using H-1 NMR-based metabolomic study." Analytica Chimica Acta. 648(1), pp. 71-76. 2009. https://doi.org/10.1016/j.aca.2009.06.039

[15] Bellomarino, S. A., Parker, R. M., Conlan, X. A., Barnett, N. W., Adams, M. J. "Partial least squares and principal components analysis of wine vintage by high performance liquid chromatography with chemiluminescence detection." Analytica Chimica Acta. 678(1), pp. 34-38. 2010. https://doi.org/10.1016/j.aca.2010.08.021

[16] Rogerson, F. S. S., De Freitas, V. A. P. "Fortification spirit, a contributor to the aroma complexity of port." Journal of Food Science. 67(4), pp. 1564-1569. 2002.

https://doi.org/10.1111/j.1365-2621.2002.tb10323.x 
[17] Majoros, E. L., Csoka, M., Korany, K. "Sárgabarack-gyümölcs, -pálinka és -szeszesital aromatulajdonságainak feltérképezése GC-MS vizsgálatokkal." (Mapping of aromatic characteristics of apricot fruit, pálinka and alcoholic beverages by GC-MS methods.) Élelmiszervizsgálati Közlemények. 52(2), pp. 77-84. 2006. (in Hungarian)

[18] Satora, P., Tuszynski, T. "Chemical characteristics of Sliwowica Lacka and other plum brandies." Journal of the Science of Food and Agriculture. 88(1), pp. 167-174. 2008. https://doi.org/10.1002/jsfa.3067

[19] OMSZ. Hungarian climatic datadase. 2015. [Online]. Available form: http://www.met.hu/ [Accessed: 20th October 2015]

[20] El Hadi, M. A. M., Zhang, F. J., Wu, F. F., Zhou, C. H., Tao, J. "Advances in Fruit Aroma Volatile Research." Molecules. 18(7), pp. 8200-8229. 2013. https://doi.org/10.3390/molecules 18078200

[21] des Gachons, C. P., Van Leeuwen, C., Tominaga, T., Soyer, J. P., Gaudillere, J. P., Dubourdieu, D. "Influence of water and nitrogen deficit on fruit ripening and aroma potential of Vitis vinifera $\mathrm{L} \mathrm{cv}$ Sauvignon blanc in field conditions." Journal of the Science of Food and Agriculture. 85(1), pp. 73-85. 2005. https://doi.org/10.1002/jsfa.1919

[22] Salas, N. A., Molina-Corral, F. J., Gonzalez-Aguilar, G. A., Otero, A., Sepulveda, D. R., Olivas, G. I. "Volatile production by 'Golden Delicious' apples is affected by preharvest application of aminoethoxyvinylglycine." Scientia Horticulturae. 130(2), pp. 436-444. 2011.

https://doi.org/10.1016/j.scienta.2011.07.017

[23] Tietel Z, Lewinsohn E, Fallik E, Porat R (2012) "Importance of storage temperatures in maintaining flavor and quality of mandarins." Postharvest Biology and Technology. 64(1), pp. 175-182. 2012. https://doi.org/10.1016/j.postharvbio.2011.07.009

[24] Dixon, J., Hewett, E. W. "Factors affecting apple aroma/flavour volatile concentration: a review." New Zealand Journal of Crop and Horticultural Science. 28(3), pp. 155-173. 2000. https://doi.org/10.1080/01140671.2000.9514136

[25] López, M. L., Villatoro, C., Fuentes, T., Graell, J., Lara, I., Echeverría, G. "Volatile compounds, quality parameters and consumer acceptance of 'Pink Lady ${ }^{\circledR}$ ' apples stored in different conditions." Postharvest Biology and Technology. 43(1), pp. 55-66. 2007.

https://doi.org/10.1016/j.postharvbio.2006.07.009

[26] Lopez, M. L., Lavilla, M. T., Riba, M., Vendrell, M. "Comparison of volatile compounds in two seasons in apples: Golden Delicious and Granny Smith." Journal of Food Quality. 21(2), pp. 155-166. 1998. https://doi.org/10.1111/j.1745-4557.1998.tb00512.x

[27] Villatoro, C., Altisent, R., Echeverria, G., Graell, J., Lopez, M. L., Lara, I. "Changes in biosynthesis of aroma volatile compounds during on-tree maturation of 'Pink Lady ${ }^{\circledR}$ ' apples." Postharvest Biology and Technology. 47(3), pp. 286-295. 2008.

https://doi.org/10.1016/j.postharvbio.2007.07.003
[28] Rowan, D. D., Lane, P. H., Allen, M. J., Fielder, S., Hunt, B. M. "Biosynthesis of 2-methylbutyl, 2-methyl-2-butenyl, and 2-methylbutanoate esters in red delicious and Granny Smith apples using deuterium-labeled substrates." Journal of Agricultural and Food Chemistry. 44(10), pp. 3276-3285. 1996.

https://doi.org/10.1021/jf9508209

[29] Fuhrmann, E., Grosch, W. "Character impact odorants of the apple cultivars Elstar and Cox Orange." Molecular Nutrition \& Food Research. 46(3), pp. 187-193. 2002.

https://doi.org/10.1002/1521-3803(20020501)46:3<187::AIDFOOD187>3.0.CO;2-5

[30] Gómez-Plaza, E., Ledbetter, C. "The Flavor of Plums." In: Handbook of Fruit and Vegetable Flavors. (Hui, Y. H. (ed.)) John Wiley \& Sons, Inc., Hoboken, NJ, USA. 2010. https://doi.org/10.1002/9780470622834.ch22

[31] Gonzalez-Cebrino, F., Garcia-Parra, J., Ramirez, R. "Aroma profile of a red plum puree processed by high hydrostatic pressure and analysed by SPME-GC/MS." Innovative Food Science \& Emerging Technology. 33, pp. 108-114. 2016.

https://doi.org/10.1016/j.ifset.2015.11.008

[32] Chai, Q. Q., Wu, B. H., Liu, W. S., Wang, L. J., Yang, C. X., Wang, Y. J., Fang, J. B., Liu, Y. C., Li, S. H. "Volatiles of plums evaluated by HSSPME with GC-MS at the germplasm level." Food Chemistry. 130(2), pp. 432-440. 2012.

https://doi.org/10.1016/j.foodchem.2011.05.127

[33] Nunes, C., Coimbra, M. A., Saraiva, J., Rocha, S. M. "Study of the volatile components of a candied plum and estimation of their contribution to the aroma." Food Chemistry. 111(4), pp. 897-905. 2008.

https://doi.org/10.1016/j.foodchem.2008.05.003

[34] Jackowetz, J. N., Dierschke, S., Mira de Orduña, R. "Multifactorial analysis of acetaldehyde kinetics during alcoholic fermentation by Saccharomyces cerevisiae." Food Research International. 44(1), pp. 310-316. 2011. https://doi.org/10.1016/j.foodres.2010.10.014

[35] Fernandez-Trujillo, J. P., Nock, J. F., Watkins, C. B. "Superficial scald, carbon dioxide injury, and changes of fermentation products and organic acids in 'Cortland' and 'Law Rome' apples after high carbon dioxide stress treatment." Journal of the American Society for Horticultural Science. 126(2), pp. 235-241. 2001.

[36] Lammertyn, J., Scheerlinck, N., Jancsok, P., Verlinden, B. E., Nicolai, B. M. "A respiration-diffusion model for 'Conference' pears I: model development and validation." Postharvest Biology and Technology. 30(1), pp. 29-42. 2003.

https://doi.org/10.1016/S0925-5214(03)00061-9 